\title{
Tata Kelola Desa Wisata Berbasis CHSE di Desa Bakas Kabupaten Klungkung
}

\begin{abstract}
Hanugerah Kristiono Liestiandre1, Dewa Ayu Made Lily Dianasari2*, Ni Made Tirtawati ${ }^{3}$, Hartanti Woro Susianti ${ }^{4}$, Ida Bagus Putra Negarayana ${ }^{5}$, Ni Luh Nyoman Tri Lilasari6, I Gede Gian Saputra7, Dewa Ayu Nyoman Aridayanti ${ }^{8}$
\end{abstract}

1,2,3,4,5,6,7,8Program Studi Manajemen Kepariwisataan, Politeknik Pariwisata Bali

Jl. Dharmawangsa Kampial, Nusa Dua Bali, Telp: (0361) 773537

${ }^{1}$ hanugerah@ppb.ac.id, ${ }^{2 * l i l y . d i a n a s a r i @ g m a i l . c o m, ~}{ }^{3}$ tirtastp@yahoo.co.id, ${ }^{4}$ worosusianti@ppb.ac.id ${ }^{5}$ negarayana@ppb.ac.id, 6trililasari_ila@ppb.ac.id, ${ }^{7}$ giansaputra@ppb.ac.id, ${ }^{8}$ rid@ppb.ac.id

* Penulis Korespondesi

\begin{tabular}{l|l|l} 
Received: September, 2021 & Accepted: November, 2021 & Published: December, 2021
\end{tabular}

\begin{abstract}
The managers and community leaders of Bakas Village admit that they are not ready to manage their village as a tourism village. Another problem is that good governance has not been established in terms of developing a tourism village and there are several conditions for local communities who are not ready to provide services to tourists who come because there is no clear management system. This community service is carried out in 3 stages with participants from all stakeholders. tourist village. The end result of this community service is to increase public understanding of the CHSE-based tourism village governance system, the formation of a tourism management system managed by a professional management agency in the Bakas Village area that accommodates the aspirations of local communities, and increasing the community's ability to provide excellent service with CHSE-based.
\end{abstract}

Keywords: governance, tourism village, CHSE

\begin{abstract}
Abstrak
Pengelola dan tokoh masyarakat Desa Bakas mengaku belum siap dengan tata kelola desanya sebagai desa wisata. Permasalahan lainnya adalah belum terbentuknya tata kelola yang baik dalam hal pengembangan desa wisata dan terdapat beberapa kondisi masyarakat lokal yang belum siap memberikan pelayanan terhadap wisatawan yang datang dikarenakan belum adanya system pengelolaan yang jelas Pengadian kepada masyarakat ini dilakukan dalam 3 tahap dengan peserta dari seluruh pemangku kepentingan desa wisata. Hasil akhir pengabdian kepada masyarakat ini untuk meningkatkan pemahaman masyarakat tentang sistem tata kelola desa wisata berbasis CHSE, terbentuknya sistem tata kelola pariwisata yang dikelola oleh suatu lembaga badan pengelola profesional di wilayah Desa Bakas yang mengakomodir aspirasi masyarakat lokal, dan meningkatnya kemampuan masyarakat dalam memberikan pelayanan prima berbasis CHSE.
\end{abstract}

Kata kunci: tata kelola, desa wisata, CHSE 


\section{PENDAHULUAN}

Memberikan kebebasan pengelolaan sebuah destinasi pariwisata, khususnya sebuah desa, dengan meningkatkan partisipasi masyarakat lokal dalam pengelolaan dan pengambilan keputusan tidak sepenuhnya menjadi acuan bagi masyarakatnya sendiri (Lekaota, 2015). Masyarakat lokal saat ini seharusnya mampu mendapatkan keuntungan lebih banyak dari adanya aktivitas pariwisata di wilayahnya. Pariwisata berbasis komunitas (community-based tourism) adalah sebuah konsep yang menekankan masyarakat untuk mampu mengelola dan mengembangkan daya tarik wisata oleh masyarakat itu sendiri. Pemberdayaan masyarakat atau komunitas lokal merupakan paradigma yang sangat penting dalam kerangka pengembangan dan atau pengelolaan sumberdaya budaya dan pariwisata.

Wujud dari konsep community-based tourism adalah dikembangkannya desa-desa wisata, dimana dalam desa wisata, masyarakat desa yang berada di wilayah pariwisata mengembangkan potensinya baik potensi sumber daya alam, budaya, dan juga potensi sumber daya manusianya. Keberadaan desa wisata di Indonesia saat ini sudah semakin berkembang pesat. Selanjutnya desa wisata adalah suatu bentuk integrasi antara atraksi, akomodasi dan fasilitas pendukung yang disajikan dalam suatu struktur kehidupan masyarakat yang menyatu dengan tata cara dan tradisi yang berlaku (Nuryanti, 1993). Pengembangan desa wisata dapat memberikan dampak positif bagi masyarakat desa itu sendiri, diantaranya adalah akan adanya lahan pekerjaan baru bagi masyarakat sehingga dapat menurunkan angka pengangguran di desa tersebut, selain itu desa wisata yang mengusung konsep ekowisata akan membuat suatu desa dapat mempertahankan kelestarian alam dan budaya desanya. Hal lainnya adalah desa wisata dapat membuat suatu desa menjadi desa yang mandiri karena dapat menyediakan alternatif pekerjaan yang dapat dimasuki oleh masyarakat setempat. Keterlibatan masyarakat dalam pengembangan sebuah destinasi akan memberikan dampak pada pertumbuhan ekonomi dan perbaikan lingkungan yang lebih baik (Latip et al, 2018).

Desa wisata saat ini memiliki kecenderungan menggunakan konsep ekowisata, dimana pariwisata yang ditawarkan adalah segala potensi yang dimiliki oleh masyarakat pedesaan. Pariwisata pedesaan menjadikan masyarakat lebih menjaga keaslian budaya dan alam di desanya untuk dapat mempertahankan minat wisatawan dalam berwisata di desa wisata. Desa Wisata memiliki ciri dan nilai tertentu yang dapat menjadi daya tarik khusus bagi wisatawan minat khusus (special interest tourist) terhadap kehidupan pedesaan (Inskepp, 1991). Konsep yang digunakan dalam CBT sangat erat kaitannya dengan pemberdayaan, dimana masyarakat diberdayakan terlebih dahulu agar mampu mengembangkan potensinya sendiri, dengan pemberdayaan masyarakat dilatih untuk bisa menolong dirinya sendiri (self help), sehingga pada pembangunan desa wisata, masyarakat dikembangkan dan diberdayakan untuk mampu mengelola desa wisatanya sendiri. Keterlibatan masyarakat dapat membuat distribusi manfaat dan biaya lebih efisien dan lebih adil, dan yang lebih penting dpat membantu mengubah proses pengembangan diri masyarakat dan berbagi pengetahuan. Dalam konteks pariwisata yang berkelanjutan, keterlibatan masyarakat mengacu pada pengembangan sistem yang memberikan semua kelompok komunitas pemangku kepentingan partisipasi penuh yang relevan dalam pengambilan keputusan kolaboratif, dan kepemilikan bersama atas tanggung jawab dan manfaat (Li \& Hunter (2015). Pengembangan destinasi pariwisata yang berbasis pada alam dan lingkungan akan sangat membutuhkan terlibatan diantara pemangku kepentingan untuk memiliki etika yang berwawasan lingkungan lebih kuat (Holden, 2018).

Terjadi situasi Pandemi Covid-19 akhirnya menguji kemandirian desa wisata. Desa wisata yang sebelumnya memiliki banyak pemasukan dari kegiatan wisata kini harus mengatur ulang strategi untuk tetap bertahan dengan kemandirian yang dibentuk. Satu 
kekuatan yang menjadi keuntungan dari desa wisata adalah tidak hilangnya pekerjaan utama masyarakat. Menurut Adnyani (2020), Bali adalah tujuan wisata utama, perlu untuk mengambil langkah segera dan cepat untuk memulihkan semua tujuan wisata yang terkena dampak. Pandemi virus corona memengaruhi tenaga kerja yang bergantung pada pariwisata Bali. Hampir semua tujuan wisata, atraksi, dan fasilitas ditangguhkan atau ditutup sejak keadaan darurat diberlakukan secara nasional. Beberapa hasil penelitian mengungkapkan bahwa kedepan akan terjadi perubahan perilaku wisatawan dalam berwisata. Yang menarik adalah desa wisata menjadi salah satu alternatif karena memiliki potensi besar untuk dikunjungi pasca pandemik atau di kehidupan normal yang baru (The New Normal). Oleh karena itu, kesiapan desa wisata dalam memberikan pelayanan akan turut menentukan citra Bali dimata pariwisata internasional. Ketika idetitas sosial dapat dibangun, baik melalui perilaku wisatawan, terlebih pada masyarakat lokal yang terlibat dalam pengembangan pariwisatanya, akan terbangun advokasi yang baik terhadap destinasi tersebut (Wang et al, 2014; Skinner, 2018), disamping juga untuk menilai dampak negatif yang ditimbulkan akibat dari pariwisata (Gursoy et al, 2018)

Kabupaten Klungkung merupakan salah satu kabupaten di Bali yang juga mengembangkan desa wisata sebagai wujud pengembangan community-based tourism dan diharapkan mampu memberikan manfaat bagi masyarakat lokal. Berdasarkan Perbup Nomor 2 Tahun 2019 telah ditetapkan sebanyak 18 desa wisata, yang 9 desa wisata di antaranya berada di Klungkung daratan dan 9 lainnya berada di Kepulauan Nusa Penida. Wakil Bupati Klungkung I Made Kasta, mengatakan bahwa sejumlah desa yang telah ditetapkan sebagai desa wisata tersebut diakui belum mengalami perkembangan yang disebabkan oleh minimnya pengetahuan masyarakat lokal tentang pariwisata (Radar Bali, 2019). Salah satu desa wisata yang dikembangkan di Kabupaten Klungkung adalah Desa Wisata Bakas. Desa wisata Bakas mulai dikembangkan sejak tahun 2017 dengan menawarkan atraksi berupa wisata tracking di areal persawahan. Selain itu, setelah setahun dikembangkan, Desa Wisata Bakas menambah atraksi wisata dengan membuat spot swafoto untuk menarik minat wisatawan untuk berkunjung sesuai tren yang berkembang saat ini. Sebagai sebuah desa wisata, Desa Bakas merupakan desa yang memiliki potensi yang kuat untuk dikembangkan namun melihat dari sumber daya yang ada, desa ini pesimis untuk mengembangkan desanya.

Masyarakat sekitar Desa Bakas ini sebagian besar bekerja mengandalkan sektor pertanian. Hal ini dikarenakan desa bakas memiliki lahan sawah yang luas sehingga membuat masyarakat sebagian besar lebih memilih menjadi petani. Aktivitas pertanian di Desa Bakas masih dilakukan secara tradisional sehingga kesan pedesaannya pun terasa semakin kental. Selain menjadi petani, ada beberapa masyarakat yang bekerja sebagai peternak, pegawai negeri, buruh, pedagang dan yang lainnya. Hasil produksi utama di Desa Bakas yaitu padi. Hal ini dikarenakan sebagian besar masyarakat sebagai petani dan petani di Desa Bakas lebih sering menanam padi. Selain itu hasil produksi lainnya yaitu jaje bali dan minyak kelapa.

Berdasarkan penjajagan yang telah dilakukan, pengelola dan tokoh masyarakat Desa Bakas mengaku belum siap dengan tata kelola desanya sebagai desa wisata. Permasalahan lainnya yang terjadi saat ini di Desa Bakas adalah belum terbentuknya tata kelola yang baik dalam hal pengembangan desa wisata. Masih terdapat beberapa kondisi masyarakat lokal yang belum siap memberikan pelayanan terhadap wisatawan yang datang dikarenakan belum adanya system pengelolaan yang jelas. Disisi lain, kondisi pandemic Covid-19 merupakan momentum untuk menyiapkan segala hal terkait pengembangan desa wisata. Pandemi ini pun mendorong bagi setiap desa wisata agar mampu memberikan pelayanan berdasarkan protokol kesehatan (CHSE). Sehingga, ketika nanti desa wisata telah siap dan kondisi pariwisata kembali normal, desa wisata Bakas dapat menjadi pilihan untuk dikunjungi wisatawan dan mampu memperoleh manfaat yang 
Dewa Ayu Made Lily Dianasari, Hanugerah Kristiono Liestiandre, Ni Made Tirtawati, dkk

positif bagi bagi masyarakat lokal. Oleh karena itu perlu adanya pendampingan secara terus menerus terutama dari pihak akademisi guna membentuk keterampilan masyarakat agar mandiri dalam mengelola potensi desa wisata secara berkelanjutan. Pelatihan dan pendidikan merupakan kebutuhan mendesak bagi pemerintah, organisasi, akademisi, dan LSM untuk bermitra secara kolektif mengembangkan kampanye dan untuk pengembangan modal manusia dan sosial khususnya kepada masyrakat lokal (Tasci et al, 2014).

\section{METODE PELAKSANAAN KEGIATAN}

Kegiatan dilaksanakan sampai pada tahap evaluasi, untuk melihat sejauh mana keberhasilan dari kegiatan pelatihan tersebut. Dari evaluasi ini, masyarakat akan mengetahui apa yang sudah dilakukan, apa yang belum dan apa yang harus dilakukan pada tahap selanjutnya. Peserta kegiatan diikuti oleh perangkat desa dan seluruh lapisan masyarakat Desa Bakas sebagai bagian dan pengelola Desa Bakas. Pelaksanaan kegiatan pengabdian kepada masyarakat terdiri dari 3 tahap pelaksanaan, yaitu:

1) Tahap 1

Pendampingan Tata Kelola Desa Wisata di Desa Bakas. Kegiatan ini difokuskan pada membangun desa wisata dan tata kelolanya melalui studi kasus yang terjadi di Desa Penglipuran, Kabupaten Bangli, dan Desa Kedonganan, Kabupaten Badung.

2) Tahap 2

Pendampingan Tata Kelola Desa Wisata Berbasis CHSE di Desa Bakas.Kegiatan ini difokuskan pada pengelolaan desa wisata berbasis CHSE dari forum Komunikasi Desa Wisata (FORKOM DEWI) Provinsi Bali dan program kerja Desa Wisata Bakas. iatan Pendampingan tahap 2 adalah kegiatan dengan memfokuskan pengelolaan sebuah desa wisata, dan mendengarkan pemaparan dan rencana pengelolaan Desa Wisata Bakas, yang dievaluasi oleh pembahas apa yang perlu dilakukan pada setia tahapan pengeloalaan desa wisata dan apa yang dipandang perlu untuk diperbaiki pada pengelolaan saat ini.

3) Tahap 3

Pada tahap akhir dilakukan studi banding dan observasi lapangan di Desa Wisata Sangeh sebagai desa pembanding dalam pengelolaan desa wisata berbasis CHSE. Pendampingan dengan mengajak peserta belajar melalui Study Visit kali ini menjadi bahan perbandingan dan sekaligus pembelajaran bagi masyarakat Desa Wisata Bakas, dan juga untuk melihat sejauh mana keberhasilan dari kegiatan pelatihan ini. Melalui Kunjungan ke Desa Wisata sangeh Kabupaten Badung, masyarakat Desa Wisata Bakas mengetahui apa yang sudah dilakukan, apa yang belum dan apa yang harus dilakukan pada pengelolaan Desa Wisata mereka selanjutnya.

\section{HASIL DAN PEMBAHASAN}

\subsection{Pendampingan Tahap 1 Tata Kelola Desa Wisata di Desa Bakas \\ 3.1.1 Studi Kasus Tata Kelola Desa Penglipuran}

Desa Penglipuran dari segi Struktur Pemerintah Penglipuran adalah Lingkungan Penglipuran Kelurahan Kubu Kecamatan /Kabupaten Bangli Provinsi Bali, dari sedi adat disebut Desa Adat Penglipuran, dan dari segi pariwisata disebut Desa Wisata Penglipuran. Luas wilayah 112 hektar yang terbagi menjadi 3 wilayah, yaitu Wilayah Parahyangan yang merupakan wilayah tempat suci, WIlayah Pawongan yang merupakan pemukiman, dan Wilayah Palemahan yang terdiri atas lahan pertanian, hutan, kuburan, dan fasilitas umum. Proses Desa Penglipuran menjadi Desa Wisata diawali dengan ditetapkannya desa ini sebagai desa konservasi, dan berkembang pada tahun 1993 menjadi desa tradisional sebagai daya tarik wisata. Setelah berkembang konsep pengembangan pariwisata berbasis masyarakat, desa ini menjadi desa wisata pada tahun 2012, dan sampai saat ini terus berkembang dengan terintegrasi dengan konsep pariwisata berkelanjutan. Visi desa 
Dewa Ayu Made Lily Dianasari, Hanugerah Kristiono Liestiandre, Ni Made Tirtawati, dkk

wisata ini yaitu mengembangkan desa yang berbasis masyarakat, berbudaya, berwawasan lingkungan dengan berdasarkan Tri Hita Karana. Tata kelola desa wisata disini telah berjalan baik dengan struktur pengelola yang kuat dan telah memperhatikan setiap komponen yang dimilikinya sebagai destinasi pariwisata, baik secara administrasi maupun secara operasional. Desa Wisata Penglipuran juga menjalankan tata kelola secara kolabotarif dengan melibatkan seluruh pemangku kepentingan di atas maupun di bawah (Top Up - Top Down). Seluruh usaha dan aktivitas telah terkelola dengan baik, termasuk tata kelola terhadap finansial. Dalam masa adaptasi baru desa wisata ini telah melakukan mitigas dan pengawasan yang ketat terhadap CHSE yang dilaksanakan.

Berdasarkan studi kasus diatas, desa Bakas hendaknya dapat memulai tata kelola desanya sebagai desa wisata, dengan memulai dari melakukan pencatatan sejarah perkembangan desa, melakukan perencanaan konsep pengembangan yang akan ditetapkan sebagai pijakan dalam pengembangan desa wisata, studi potensi wisata termasuk jenis-jenis usaha dan aktivitas yang dapat dilakukan pengunjung dan wisatawan selama berada di desa wisatanya. Konsep pengembangan destinasi melalui konsep berbasis masyarakat, berkelanjutan, pemasaran destinasi, dan lainnya bisa digunakan secara terintegrasi, akan menjadi nilai tambah yang baik (Tasci, et al, 2014). Struktur organisasi yang kuat dengan disukung oleh seluruh komponen masyarakat, dan kolaborasi dengan pemangku kepentingan melalui jaringan komunikasi yang baik, akan menjadi faktor penting dalam tata kelola desa wisata ke depan. Tata kelola yang transparansi khususnya pengelolaan finansial, menjadi hal yang utama dalam prinsip tata kelola sebuah desa wisata.

\subsubsection{Studi Kasus Tata Kelola Desa Kedonganan}

Perkembangan Desa Kedonganan, awali dengan perkembangan pariwisata di Bali pada tahun 2000-an. Akibat perkembangan pariwisata itu, di daerah Jimbaran berkembang pula pusat wisata makanan ikan bakar, bagi wisatawan yang menikmati makan malam sembari menikmati suasana sunset di pinggi pantai. Di daerah Jimbaran itulah yang memberi dampak bagi Desa Kedonganan untuk ikut pula mengembangkan desanya sebagai destinasi pariwisata yang menawarkan wisata makanan ikan bakarnya. Berdirinya beberapa warung ( $c a f e$ ) yang ada di desa ini menjadi awal berkembangannya aktivitas pariwisata, hingga pada akhirnya memberikan dampak negatif, akibat tidak terkelonya dengan baik sebagai destinasi pariwisata. Hingga pada tahun 2007, bersama pemerintah daerah Kabupaten Badung menata kawasan Pantai Kedonganan. Konsep yang digunakan dalam pengelolaan mengangkat konsep kearifan lokal Tri Hita Karana, dengan mengedepankan kepentingan ekonomi masyarakat sekitar dan lingkungan desanya. Hingga saat ini pengelolaan kawasan Pantai Kedonganan dipercayakan kepada Badan Pengelola Kawasan Pantai Pesisir Kedonganan (BPKP2K), dengan lebih terintegrasi dengan seluruh pemangku kepentingan dan lapisan masyarakat yang ada. Aktivitas pariwisata juga berkembang, tidak hanya menawarkan wisata makanan saja, namun beberapa aktifitas seperti berkuda, sunset tour di atas kapal, bahkan pengembangan pariwisata tidak lagi berfokus di wilayah Pantai Kedonganan saja, namun telah ke wilayah hutan mangrove yang juga dimiliki oleh desa ini. Perkembangan Desa Kedonganan dimulai dari paradigma pariwisata adalah milik rakyat oleh rakyat dan untuk rakyat, dan pariwisata adalah tools untuk mensejahterakan masyarakat sebagai pijakan dalam tata kelolanya. Berasal dari pola pikir tersebut, dilanjutkan dengan pemahaman seluruh masrayakat desa terhadap manfaat pariwisata terhadap perdesaan dan pengertian terhadap desa wisata, agar masyarakat dapat memastikan apa yang harus dilakukannya sehingga menjadi desa wisata yang unggul. Hal ini dilakukan pada seluruh pengelolaan desa wisatanya hingga aktivitas pemasaran dari pengemasan produk, promosi, hingga pelayanan yang diberikan kepada wisatawan atau pengunjung. 
Dewa Ayu Made Lily Dianasari, Hanugerah Kristiono Liestiandre, Ni Made Tirtawati, dkk

Bagi Desa Bakas, pembelajaran melalui Desa Kedonganan menjadi hal yang penting dalam mengawali pengelolaan sebuah desa wisata. Kesepahaman dan persamaan persepsi akan tujuan dari seluruh pemangku kepentingan dan lapisan masyarakat menjadi suatu kekuatan yang besar dalam proses pengembangan desa sebagai destinasi pariwisata. Dimulai dari persamaan pola pikir hingga persamaan akan manfaat yang diperoleh jika Desa Bakas dikelola secara baik dan benar sesuai konsep pengembangan suatu destinasi pariwisata. Dari kekuatan ini akan memudahkan dalam tata kelola sebuah desa wisata dari tahap perencanaan hingga tahap pengawasan yang diperlukan dalam pengelola sebuah desa wisata, karena pada hakekatnya alam pembangunan berkelanjutan berbasis masyarakat, masyarakat lokal memiliki peran sentral dan menjadi aktor utama dalam mengelola sumber daya untuk memperoleh manfaat dari kegiatan teresebut (Baiquni \& Djulkifli, 2019).

\subsection{Pendampingan Tahap 2 Tata Kelola Desa Wisata Berbasis CHSE 3.2.1 Pandangan FORKOM DEWI Provinsi Bali}

Forum Komuikasi Desa Wisata Provinsi Bali memberikan penegasan dalam pengelolaan desa wisata, dengan tetap selalu berprinsip pada kearifan lokal yang ada di Bali, terutama Tri Hita Karana. Bali memiliki sekitar 177 desa wisata yang sudah memiliki legalitas hukum (Denpasar 6 desa, Badung 11 desa, Tabanan, 26 desa, Jembrana 6 desa, Buleleng, 31 desa, Gianyar, 24 desa, Bangli 31 desa, Karangasem 26 desa, dan Klungkung 18 desa). Pengembangan desa wisata di Bali tidak cukup hanya memperhatikan aspek 3A2P saja. Namun, dengan adanya pandemic COVID-19 perlu juga diperhatikan aspek CHSE. Selain itu, perlu juga didukung dengan integrasi digitalisasi termasuk dalam hal sistem pembayaran (ticketing), promosi online dan pendataan pengunjung. Arah pengembangan desa wisata memiliki 3 hal, yaitu pengembangan komponen destinasi pariwisata di desanya, implementasi CHSE, dan integrasi digitalisasi. Pembangunan kepariwisataan secara nasional diarahkan mulai dari mengembangkan pariwisata berbasis pada potensi dan kemampuan masyarakat dalam mengelola kegiatan pariwisata. Lnadasan hukum dalam pengembangan desa sebagai desa wisata yaitu, Undang - Undang Republik Indonesia, No.10, Tahun 2009 tentang Kepariwisataan, Perda Propensi Bali, No. 2, Tahun 2012 tentang Kepariwisataan Budaya Bali, Program Bali Mandara Jilid II, Tahun 2013 - 2018, Surat Keputusan No. 556/1664/1/Dispar Provinsi Bali, tentang pembentukan dan Susunan pengurus Forum Komunikasi Desa Wisata Bali dan Keputusan Kepala Dinas Pariwisata Provinsi Bali No. 556/1941/I/DISPARDA 2019, tentang Pembentukan dan Susunan Pengurus Forum Komunikasi Desa Wisata Bali.tahun 2019 2024. FORKUM DEWI juga menegaskan perlunya pelibatan semua pemangku kepentingan dan terbentuknya sebuah lembaga pengelolaan desa wisata yang baik, dapat berupa swadaya masyarakat, organisasi masyarakat, koperasi, maupun Badan Umum Milik Desa (BUMDes). Terkait CHSE, pengelolaan desa wisata tetap mengarah kepada pariwisata yang berkualias dan berkelanjutan dengan berbasis budaya ekonomi kreatif.

Pandangan FORKOM DEWI Provinsi Bali tersebut menjadi masukan yang berarti untuk memperkuat pengelolaan desa wisata, baik secara legalitas maupun arah pengembangan desa wisata lebih lanjut. Terutama penataan komponen destinasi pariwisata, pelaksanaan CHSE, dan digitalisasi pada Desa Bakas. Melihat sumber daya yang dimiliki oleh Desa Bakas, pengelola seharusnya dapat mengimplementasikan dengan baik selama bergerak bersama dengan seluruh pemangku kepentingan dan dukungan suluruh lapisan masyarakat.

\subsubsection{Program Kerja Desa Wisata Bakas}

Desa Bakas merupakan salah satu desa wisata yang berada di Kabupaten Klungkung. Secara umum, mata pencarian masyarakat Desa Bakas adalah bertani. Hal ini didukung 
Dewa Ayu Made Lily Dianasari, Hanugerah Kristiono Liestiandre, Ni Made Tirtawati, dkk

oleh tersedianya lahan basah yang cukup luas, dan ketersediaan air yang cukup baik dari Tukad (Sungai) Melangit. Kegiatan pariwisata juga tumbuh di Desa ini, di mana terdapat daya tarik wisata arung jeram (rafting), wisata Gajah dan pengalaman ATV. Potensi Desa Bakas ini memiliki tantangan tersendiri dalam menata kebijakan pembangunan desa, dimana kegiatan pariwisata dan pertanian dapat berjalan beriringan dan saling berkontribusi.

Saat ini Desa Bakas memiliki berbagai atraksi wisata yang dapat ditawarkan kepada pengunjung dan wisatawan. Desa Bakas juga memiliki pemandangan persawahan, yang ditunjang oleh suara-suara burung. Selain memiliki potensi alam, Desa Bakas juga memiliki atraksi budaya yang unik "mepantigan". Mepantigan merupakan seni bela diri tradisional Bali yang kerap dilakukan anak-anak di wilayah pedesaan jelang musim tanam. Lahan persawahan berlumpur merupakan tempat bagi anak-anak di pedesaan untuk melakukan atraksi seni bela diri. Mepantigan ini sangat jarang bisa ditemui di tempat lain sehingga atraksi ini ini dapat menjadi salah satu atraksi unggulan Desa Bakas.

Desa Bakas juga memiliki keunikan di bidang kulinernya. Desa Bakas terkenal akan jajanan Balinya yang begitu nikmat. Jajanan Bali yang dapat ditemui disini yaitu laklak, pisang rai, bubuh sumsum, injin, ongol - ongol, dan yang lainnya. Namun meskipun terdapat aneka jenis jajanan Bali yang ada disini, yang paling banyak dicari oleh wisatawan yaitu jajanan laklak. Laklak yang ada di Desa Bakas begitu nikmat dan aromanya yang khas. Hal ini dikarenakan laklak disini dibuat dengan alat - alat yang sangat tradisional. Selain jajanan Bali, wisatawan dapat menikmati serombotan.

Berdasarkan segala potensi yang dimiliki oleh Desa Bakas, pengelola terus berupaya menyesuaikan diri dan beradaptasi terhadap perkembangan pariwisata saat ini, khususnya saat pandemi berlangsung. Walapun masih memiliki banyak tantangan dan keterbatasan yang dihadapi oleh pengelola, tata kelola yang ideal belum dapat dicapai secara optimal. Dukungan dari pemangku kepentingan sangat dibutuhkan baik secara finansial, fisik, maupun pemberdayaan sumber daya manusianya.

\subsection{Pendampingan Tahap 3: Studi Banding ke Desa Wisata Sangeh}

Guna memajukan Desa Wisata Bakas sekaligus juga untuk peningkatan PAD, maka Program Studi Manajemen Kepariwisataan Poltekpar Bali kembali melaksanakan kegiatan pendampingan tata kelola desa wisata tahap ketiga. Adapun kegiatan ini dihadiri oleh Bendesa Adat Bakas, Pengelola Desa Wisata Bakas beserta para tokoh desa dan Anggota Pokdarwis. Studi banding dilaksanakan ke Desa Wisata Sangeh Kabupaten Badung.

Kegiatan studi banding diterima oleh Bendesa Adat Sangeh dan Ketua Desa Wisata Sangeh Bapak Ida Bagus Dwipayana. Dalam paparan Ketua Desa Wisata Sangeh menjelaskan bahwa DTW Sangeh itu berawal dari Tahun 1970 dan setelah berproses puncaknya di Tahun 1977 pada saat Pelaksanaan PATA kemudian pada Tahun 1979 DTW Sangeh mendapatkan juara Nasional dalam lomba Kelompok Sadar Wisata, Desa Sangeh menjadi Desa Wisata No 11 yang berada di Kabupaten Badung berdasarkan surat Peraturan Bupati No 47 Tahun 2010. 


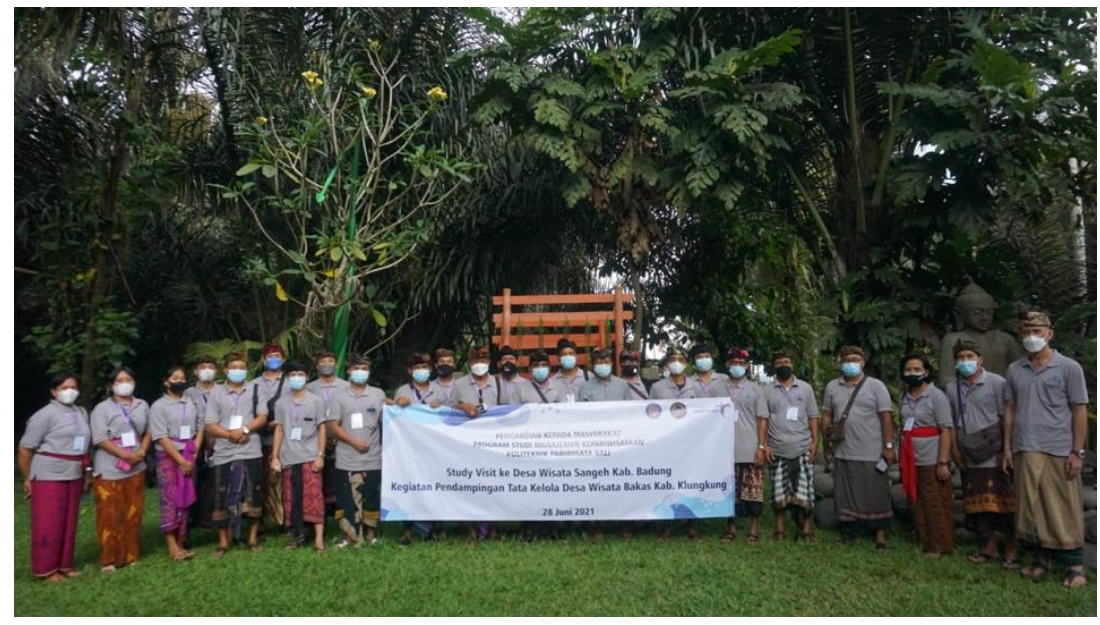

Gambar 1. Studi Banding Pengelola Desa Wisata Bakas ke Desa Wisata Sangeh

\section{KESIMPULAN}

Kegiatan pendampingan merupakan kegiatan yang paling baik dalam tata kelola sebuah desa wisata, dari tiga tahapan yang direncanakan. Dari tahap 1 dan tahap-tahap selanjutnya menjadi tahapan yang berkesinambungan dalam membangun kesadaran masyarakat untuk mengelola desanya sebagai desa wisata. Perlu diadakan kembali pendampingan tahap-tahap berikutnya, khuusnya berupa pelatihan terkait penerapan protokol kesehatan CHSE. Pendampingan berupa studi kasus dan studi banding, hingga tahap evaluasi untuk melihat sejauh mana keberhasilan dari kegiatan ini dilakukan. Dari evaluasi ini, masyarakat akan mengetahui apa yang sudah dilakukan, apa yang belum dan apa yang harus dilakukan pada tahap selanjutnya. Kegiatan dengan memfokuskan pengelolaan sebuah desa wisata, dan mendengarkan pemaparan dan rencana pengelolaan Desa Wisata Bakas, yang dievaluasi oleh pembahas apa yang perlu dilakukan pada setiap tahapan pengeloalaan desa wisata dan apa yang dipandang perlu untuk diperbaiki pada pengelolaan saat ini, menjadi dasar pijakan pengelola untuk mengevaluasi dirinya apakah selama ini pengelolaan sebuah desa wisata sudah sesuai atau belum dengan dasar-dasar pengelolan desa wisata.

Pendampingan dengan mengajak peserta belajar melalui Study Visit kali ini diharapkan menjadi bahan perbandingan dan sekaligus pembelajaran bagi masyarakat Desa Wisata Bakas, dan juga untuk melihat sejauh mana keberhasilan dari kegiatan pelatihan ini. Dari Kunjungan ke Desa Wisata sangeh Kabupaten Badung, diharapkan juga masyarakat Desa Wisata Bakas akan mengetahui apa yang sudah dilakukan, apa yang belum dan apa yang harus dilakukan pada pengelolaan Desa Wisata mereka selanjutnya. Kegiatan Pengabdian kepada Masyarakat dengan tema "Pendampingan Tata Kelola Desa Wisata Berbasis CHSE di Desa Bakas di Kabupaten Klungkung" ini dapat terlaksana sesuai dengan perencanaan dan dapat memberikan manfaat bagi perkembangan pariwisata pada umumnya dan Desa Wisata Bakas pada khususnya. Sebagai evaluasi, konsep CBT akan lebih baik jika terintegrasi dengan konsep pariwisata berkelanjutan, pengembangan pariwisata, pemasaran destinasi dan pencitraan destinasi untuk lebih memperkuat arah destinasi di masa yang akan dating (Tasci et al, 2014).

\section{DAFTAR PUSTAKA}

Adnyani. (2020). Pulihkan Pariwisata dan Ekonomi Kreatif, Kemenparekraf Siapkan Program CHSE https://travel.kompas.com/read/2020/05/15/164332127/pulihkan- 
pariwisata-dan-ekonomi-kreatif-kemenparekraf-siapkan-programchs?page=all. diunduh pada 15 Mei 2020

Baiquni, M. \& Dzulkifli, M. (2019), "Implementing Community-based Tourism", Delivering Tourism Intelligence (Bridging Tourism Theory and Practice. Emerald Publishing Limited, Bingley, 11, 6175. https://doi.org/10.1108/S2042-144320190000011006

Gursoy, D., Ouyang, Z., Nunkoo, R., \& Wei, W. (2018). Residents' Impact Perceptions of And Attitudes Towards Tourism Development: A Meta-Analysis. Journal of Hospitality Marketing \& Management, 1-28. doi: 10.1080/ 19368623.2018 .1516

Holden, A. (2018). Environmental ethics for tourism- the state of the art. Tourism Review. doi:10.1108/tr-03-2017-0066

Inskeep, E. (1991). Tourism planning: an integrated and sustainable development approach.. New York : Van Nostrand Reinhold

Latip, N. A., Rasoolimanesh, S. M., Jaafar, M., Marzuki, A., \& Umar, M. U. (2018). Indigenous residents' perceptions towards tourism development: a case of Sabah, Malaysia. Journal of Place Management and Development. doi:10.1108/jpmd-09-2017-0086

Lekaota, L. (2015). The importance of rural communities' participation in the management of tourism management. Worldwide Hospitality and Tourism Themes, 7(5), 453-462. doi:10.1108/whatt-06-2015-0029

Li, Y., \& Hunter, C. (2015). Community involvement for sustainable heritage tourism: a conceptual model. Journal of Cultural Heritage Management and Sustainable Development, 5(3), 248-262. doi:10.1108/jchmsd-08-2014-0027

Nuryanti, Wiendu. (1993). Concept, Perspective and Challenges, makalah bagian dari Laporan Konferensi Internasional mengenai Pariwisata Budaya. Yogyakarta: Gadjah Mada University Press.

Peraturan Bupati Klungkung Nomor 2 Tahun 2019

Skinner, H. (2018). The impact of cultural values and economic constraints on tourism businesses' ethical practices. International Journal of Tourism Cities. doi:10.1108/ijtc-12-2017-0087

Suharto (2006). Buku panduan Pemberdayaan Masyarakat Desa Wisata Berbasis Pendampingan. 2020. Direktorat Pengembangan SDM Pariwisata Kementerian Pariwisata dan Ekonomi Kreatif Tahun 2020.

Tasci A. D.A., Croes, R., \& Villanueva, B. J. (2014). Rise and fall of community-based tourism - facilitators, inhibitors and outcomes. Worldwide Hospitality and Tourism Themes, 6(3), 261-276. doi:10.1108/whatt-03-2014-0012

Wang, S., Zhou, L., Lee, S., \& King, C. (2014). Analysis of Residents' Social Identity, Tourism Engagement, and Propensity for Tourism Advocacy. Advances in Hospitality and Leisure, 109-129. doi:10.1108/s1745354220140000010006 